\title{
Mutagenic Sensitivity in Early Generation in Black Gram (Vigna mungo L. Hepper).
}

\author{
Asad Ali $^{1 *}$ Salma Hayat ${ }^{2}$ and U. Kr. Deka ${ }^{3}$ \\ 1,2( (Department of Botany, University of Science and Technology Meghalaya, India.) \\ ${ }^{3}$ (KVK, Nagaon, Assam Agricultural University, Assam, India.)
}

\begin{abstract}
The investigation was conducted with the aim of artificial induction of mutation by sodium azide (SA) to overcome the limitation of variability in black gram and to induce specific improvement without disturbing their better attributes. Seeds of two varieties of urdbean viz. KU92-1 and KU300 were treated with SA of different concentrations $(0.5 \%, 1.0 \%, 1.5 \%)$ to determine their mutagenic sensitivity in terms of seed germination, seedling height, number of branches/plant, number of leaves/plant, root length, root lets number/plant etc. One part of the mutagen treated seeds as well as the control of both the varieties were sown in plastic petri dishes and grown under room temperature and other part was planted in the experimental field following randomized block design (RBD) layout to raise first mutant generation $\left(M_{I}\right)$. With increase in the dose of SA, germination percentage, seedling growth and number of leaves/plant etc. were decreased. Both the parental varieties differed significantly between themselves for both percentage seed germination, seedling height and most of the characters at seedling stage for SA treatments. KU300 were highly sensitive and did not germinate in all treatments under field conditions. Variances among treatments were also significantly high.
\end{abstract}

Key words: Urdbean, sodium azide, mutagen, random block design, mutant generation

\section{Introduction}

Black gram (Vigna mungo (L.) Hepper) is an erect, fast-growing annual, herbaceous legume reaching $30-100 \mathrm{~cm}$ in height. It has a well-developed taproot and its stems are diffusely branched from the base. It is valued for its high digestibility and freedom from flatulence effect [1]. It is a summer pulse crop with short duration $(90-120)$ days and high nutritive value [2]. Black gram is used for human food, green manure, a cover crop, forage, silage, hay and chicken pasture [3]. Although, India has the distinction of being the world's single largest producer of pulses, the difference in production and population ratio is significant. The increase in population has pushed up demand of pulses while the fall in availability has pushed up their prices. Although a large area is under different pulse crops including urdbean, their production is more or less stagnant for the last four decades [4].

Most of the traits of a plant breeder's interests are quantitative traits, which are controlled by polygenic interactions. A series of experiments carried out with various crops have established that chemical mutagens induce polygenic variability [5-8]. Limited variability is available for its improvement programmes in a self pollinated crop like urdbean, Variability in base population is essential for breeding for more complex traits. Induced mutagenesis thus seems to be an ideal methodology for the induction of desirable genetic variability. Mutation breeding is one of the conventional breeding methods in plant breeding. It is relevant with various fields like, morphology, cytogenetic, biotechnology, and molecular biology etc. Mutation breeding has become increasingly popular in recent times as an effective tool for crop improvement [9] and an efficient means supplementing existing germplasm for cultivar improvement in breeding program's [10]. It was reported that mutagens may cause genetic changes in an organism, break the linkages and produce many new promising traits for the improvement of crop plants [11]. Mutagenesis has been widely used as a potent method of enhancing variability for crop improvement. By varying the mutagenic agent dose, the frequency and saturation of mutations can be regulated [12] and mutagenic agents can induce different extensions of genomic lesions, ranging from base mutations to larger fragment insertions or deletions [13].

Chemical mutagenesis is an efficient tool used in mutation breeding programmes for improving various vital characteristics in crops. Various chemicals viz. sodium azide, hydrazine hydrate, maleic hydrazide, ethyl m ethane sulphonate etc. are in use to induce mutation. It can cause allelic mutations, small deletions and other chromosomal rearrangements. These mutations can be used to activate morphometric and reproductive changes in plants; further selection of mutant plants through a number of generations, resulting in introduction of new traits into a treated population [9]. Sodium azide is highly used with seeds to create mutation [14]. The mutagenicity is mediated through the production of an organic metabolite of azide compound [15]. Keeping in view the above facts, the present investigation was undertaken with the objectives: to induce variability and study the effect of SA in seed germination, seedling growth and some other agronomic traits under laboratory and field conditions. 


\section{Materials and Methods}

Uniform healthy seeds of two varieties of black gram (Vigna mungo (L.) Hepper) viz., KU92-1 and KU300 were employed to develop the $\mathrm{M}_{1}$ generation. The seeds were soaked in distilled water for 12 hours and then treated with three different concentrations of sodium azide $(0.5 \%, 1.0 \%$, and $1.5 \%)$ for another 12 hours. After 12 hours the treated seeds were left in running tap water for an hour to remove the residual effect of the mutagen sticking to the seed coat. One set of seeds was kept untreated in distilled water to act as control. Treated seeds from both the varieties were finally grown on plastic pots along with both the controls under room temperature to study seed germination, seedling height and root growth. One part of the treated seeds along with the control of both the varieties was planted in the field in randomized block design keeping $20 \mathrm{~cm}$ seed to seed distance and $30 \mathrm{~cm}$ row to row distance in two replicates to observe seed germination, seedling height, , plant height, number of leaves/plant and number of branch/plant in $\mathrm{M}_{1}$ generation.

1.1. Evaluation of seed germination: Seed germination was evaluated under laboratory as well as field conditions. Evaluation was done after one week from day of sowing by counting the number of seedling emerged.

1.2. Seedling height: Seedling height was observed under laboratory as well as field conditions. The observation was done on $10^{\text {th }}$ day from the day of sowing. The data were compared to that of the control to measure the effect of mutagen under different concentration.

1.3. Root growth: The seedlings planted in plastic pots in the laboratory were uprooted. It was done by giving water in excess and slowly loosening the soil then pull up each seedling in such a way that there is no damage in root. Number of rootlets and root length were observed and recorded.

1.4. Number of leaves: Number of leaves was counted on $30^{\text {th }}$ day from the day of sowing and it was compared to that of control.

1.5. Number of branch: Total numbers of branches were recorded from each plant and added for each treatment separately and divided by the total number of plant scored to calculate the mean.

1.6. Statistical evaluation: The statistical significance of the effects of $\mathrm{NaN} 3$ on the observed traits was tested by analysis of variance and differences between groups were determined by the least significant differences test, with $\mathrm{P}<0.05$ considered significant.

\section{Results and Discussions}

Induced mutagenesis has been accepted as a significant tool to break through the limitations of variability and to create variability in a short period of time. The data recorded for various traits is presented in Tables 1 to 4. It is clear from the tables that the two varieties of black gram KU300 and KU92-1 differed in response to SA treatment in seed germination, root length, number of rootlet/plant and seedling height etc.

1.7. Seed germination: The extent of reduction in seed germination was more pronounced under field conditions (Table 1). KU300 did not germinate in all the treatments except the control under the field conditions. The highest germination in percent was exhibited by the control in both the varieties in both the environments (Figure 1). Both the varieties were quite sensitive to SA. The reduction and inhibition in seed germination was found to be dose dependent and decreased linearly with an increasing lethal effect of SA concentrations. Similar observations were recorded in many crops like Vigna radiata [16-18], barley [19]; pea [20];

Figure 1. Graphical representations of the effect of SA on seed germination under laboratory and field conditions.

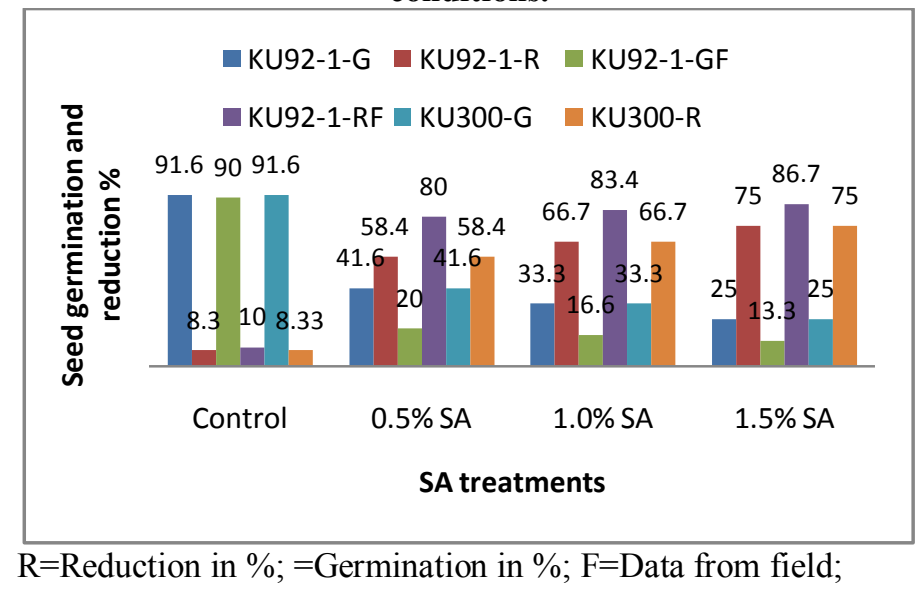


Table 1 Effect of SA on seed germination under laboratory and field conditions.

\begin{tabular}{|c|c|c|c|c|}
\hline $\begin{array}{c}\text { SA } \\
\text { Concentration } \\
\text { (in \%) } \\
\end{array}$ & $\begin{array}{c}\text { No. of } \\
\text { seed } \\
\text { sown } \\
\end{array}$ & $\begin{array}{l}\text { No. of seeds } \\
\text { germinated }\end{array}$ & $\begin{array}{l}\text { Germination } \\
\quad \text { (in } \% \text { ) }\end{array}$ & $\begin{array}{l}\text { Reduction } \\
\text { (in \%) }\end{array}$ \\
\hline \multicolumn{5}{|c|}{ KU92-1 (in the laboratory) } \\
\hline Control & 12 & 11 & 91.6 & 8.33 \\
\hline 0.5 & 12 & 5 & 41.6 & 58.4 \\
\hline 1.0 & 12 & 4 & 33.3 & 66.7 \\
\hline 1.5 & 12 & 3 & 25 & 75 \\
\hline \multicolumn{5}{|c|}{ KU300 (in the laboratory) } \\
\hline Control & 12 & 11 & 91.6 & 8.33 \\
\hline 0.5 & 12 & 5 & 41.6 & 58.4 \\
\hline 1.0 & 12 & 4 & 33.3 & 66.7 \\
\hline 1.5 & 12 & 3 & 25 & 75 \\
\hline \multicolumn{5}{|c|}{ KU92-1 (in the field) } \\
\hline Control & 30 & 27 & 90 & 10 \\
\hline 0.5 & 30 & 6 & 20 & 80 \\
\hline 1.0 & 30 & 5 & 16.6 & 83.4 \\
\hline 1.5 & 30 & 4 & 13.3 & 86.7 \\
\hline \multicolumn{5}{|c|}{ KU300 (in the field) } \\
\hline Control & 30 & 25 & 83.3 & 16.6 \\
\hline 0.5 & 30 & 0 & - & - \\
\hline 1.0 & 30 & 0 & - & - \\
\hline 1.5 & 30 & 0 & - & - \\
\hline
\end{tabular}

cowpea [21]; Vigna mungo [22], Nigella, Plantago and Trigonella [23]; Stevia rebaudiana [24].

1.8. Seedling height: Seedling height decreased in all the treatments in KU92-1. The mean height in KU92-1 ranged from $12.91 \mathrm{~cm}$ in control to $9.36 \mathrm{~cm}$ with $0.5 \% \mathrm{SA}$ treatment. It showed negative sift in mean with elevated value of coefficient of variation (Table 3, Figure 3). The maximum reduction percentage was observed to be $27.91 \%$ with $1.0 \%$ SA (Figure 2). KU300 exhibited increased height with $0.5 \%$ and $1.0 \%$ SA treatments while the same variety showed $16.47 \%$ reduction with $1.5 \%$ SA (Table 2). Reductions in seedling height due to the effect of mutagens have earlier been documented on various crop plants like barley [25], rice [26], tomato [27], Vicia faba L. [28], Pisum sativum [29] and wheat [30].

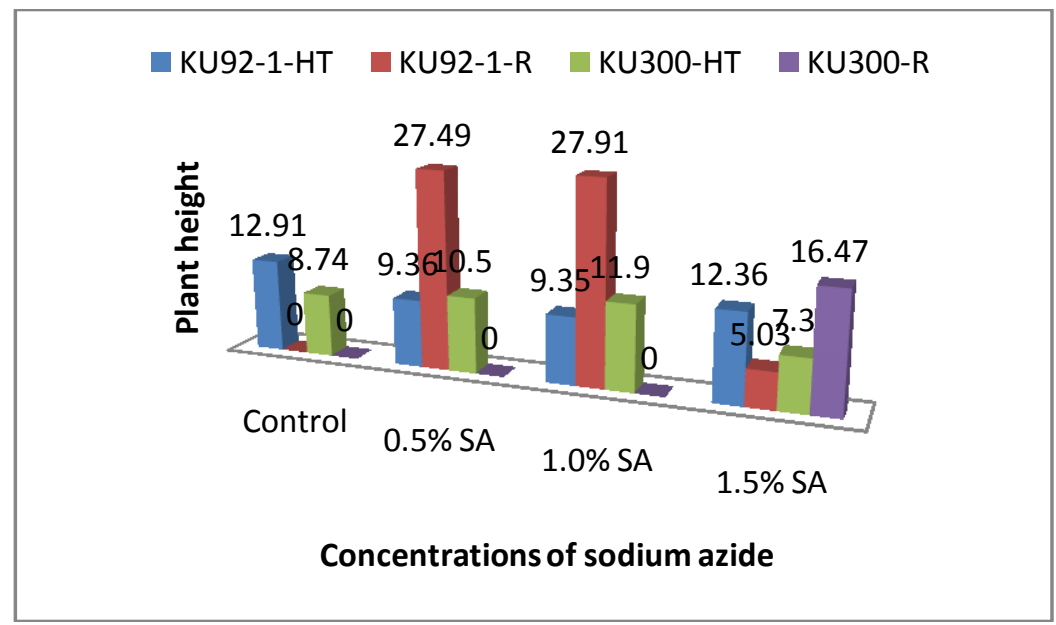

HT-Plant height, R-Reduction in \% in plant height

Figure 3: Graphical representations of seedling height between the two varieties under laboratory condition.

1.9. Root growth: The two varieties showed inter-varietal differential response to root length. It was decreased at low concentration of mutagen $(0.5 \% \mathrm{SA})$ but decreased at relatively higher doses in KU92-1. In contrast, in the variety KU300, root length was increased in all the treatments. The highest increment $(44.06 \%)$ was observed with $0.5 \% \mathrm{SA}$. The number of rootlets increased at comparatively lower concentration of SA but it was decreased with $1.5 \% \mathrm{SA}$ in both the varieties (Table 2). KU92-1 gave elevated values of VC for root growth showing further scope of improvement while KU300 gave lower CV than the control (Table 3). Similar inter and intra varietal differential response of plants in root growth due to SA application were also reported in Lycopersicon esculentum [27] and in Triticum aestivum L. [30].

1.10.Plant height : Application SA decreased plant height in all the treatments. The relationship between the quantum of reduction in plant height and dose of SA was not linear in KU92-1. The maximum reduction 
was found to be $52.05 \%$ with $1.5 \% \mathrm{SA}$ while the minimum reduction $(36.9 \%$ ) was with $1.0 \%$ SA (Figure 3 ). The present finding is in agreement with the observations in Vicia faba L. [28] and Triticum aestivum L. [30] where treatment of SA reduced the plant height significantly.

1.11.Number of leaves/plant: Number of leaves/plant was decreased in all the treatments of SA concentrations. The mean number of leaves/plant varied from 10.54 in control to 3.16 with $0.5 \% \mathrm{SA}$. The minimum reduction was $54.07 \%$ with $1.5 \% \mathrm{SA}$ and the maximum reduction was $69.25 \%$ with $0.5 \% \mathrm{SA}$ (Table 4 ). The value of reduction and amount of mutagen is non-linear. Increasing leaf area in musk okra due to treatment with SA was observed [31]. In conformity with the observation in the present findings, reduction in number of leaves/plant due to SA application have been reported in Lycopersicon esculentum L. [31].

1.12. Number of branches: Number of branches/plant was decreased significantly in all concentrations of SA in variety KU92-1 (Table 4). The reduction in number of branches in the present investigation can be related to the inhibitory effect of azide ions that binds to the enzymes involved in cellular energy production [32]. Reduction in number of branches due to higher

Table 2 Effect of sodium azide on seedling height and root growth under laboratory conditions.

\begin{tabular}{|c|c|c|c|c|c|}
\hline \multirow[t]{2}{*}{ Characters } & \multirow[t]{2}{*}{ Treatments } & \multicolumn{2}{|c|}{ Reduction (in percent) } & \multicolumn{2}{|c|}{ Increment (in percent) } \\
\hline & & KU92-1 & KU300 & KU92-1 & KU300 \\
\hline \multirow{4}{*}{$\begin{array}{l}\text { Seedling height } \\
(\mathrm{cm})\end{array}$} & Control & - & - & - & - \\
\hline & 0.5 & 27.49 & - & - & 16.76 \\
\hline & 1.0 & 27.91 & - & - & 26.55 \\
\hline & 1.5 & 5.03 & 16.47 & - & - \\
\hline \multirow[t]{4}{*}{ Root length $(\mathrm{cm})$} & Control & - & - & - & - \\
\hline & 0.5 & - & - & 10.5 & 44.06 \\
\hline & 1.0 & 9.21 & - & - & 22.77 \\
\hline & 1.5 & 2.23 & - & - & 34.74 \\
\hline \multirow{4}{*}{$\begin{array}{l}\text { Number of } \\
\text { rootlet/plant }\end{array}$} & Control & - & - & - & - \\
\hline & 0.5 & - & - & 8.3 & 22.81 \\
\hline & 1.0 & - & - & 26.7 & 23.47 \\
\hline & 1.5 & 13.64 & 53.36 & - & - \\
\hline
\end{tabular}

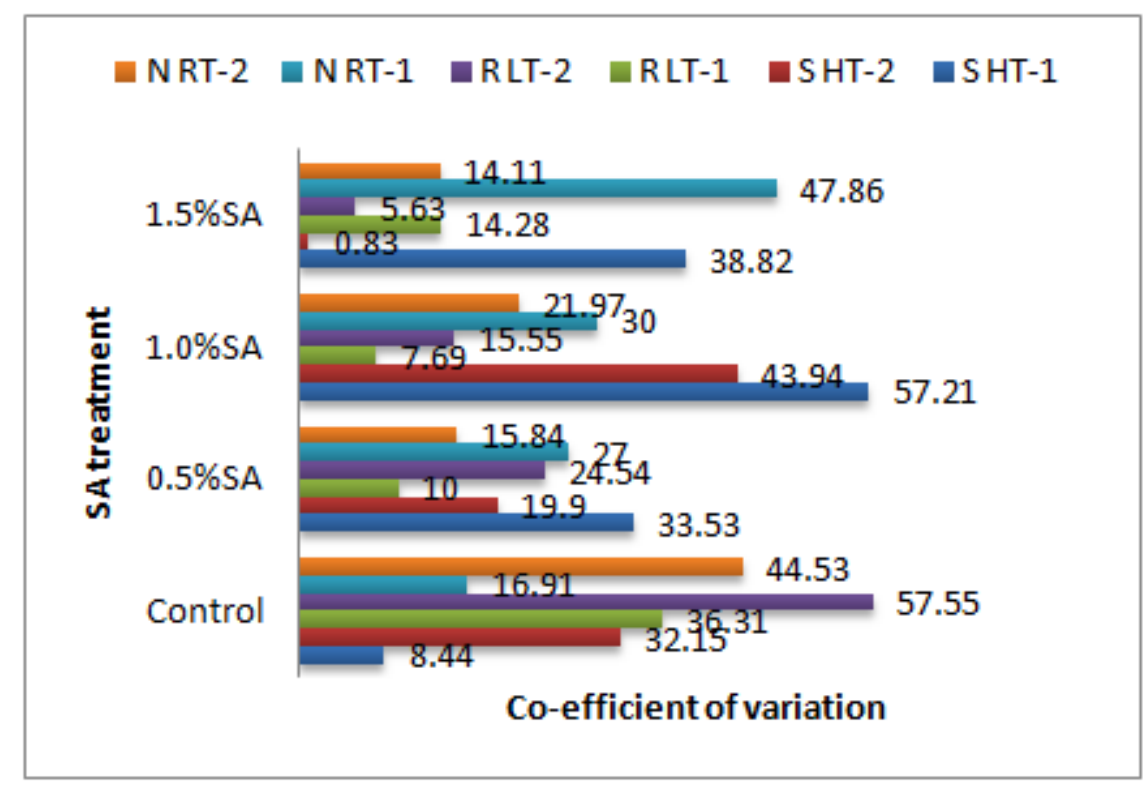

S HT=Seedling height; R LT= Root length; N RT=No. of rootlet/plant. $1=$ KU92-1; 2=KU300;

Figure 3 Graphical representations for co-efficient of variation in a few of the selected traits studied under laboratory conditions. 
Mutagenic Sensitivity in Early Generation in Black Gram (Vigna mungo L. Hepper).

Table 3 Mean, standard deviation, shift in mean and $\mathrm{CV}$ for few of selected traits as observed under laboratory conditions.

\begin{tabular}{|c|c|c|c|c|c|}
\hline Variety & Character & Treatment & Mean \pm SD & $\begin{array}{c}\text { Shift in } \\
\text { mean }\end{array}$ & $\mathrm{CV}$. \\
\hline \multirow[t]{12}{*}{ KU92-1 } & \multirow{4}{*}{$\begin{array}{l}\text { Seedling } \\
\text { height } \\
(\mathrm{cm})\end{array}$} & Control & $12.91 \pm 1.09$ & - & 8.44 \\
\hline & & $0.5 \%$ & $9.36 * * \pm 3.14$ & -3.55 & 33.53 \\
\hline & & $1.0 \%$ & $9.35 * * \pm 5.35$ & -3.56 & 57.21 \\
\hline & & $1.5 \%$ & $12.26 \pm 4.76$ & -0.65 & 38.82 \\
\hline & \multirow{4}{*}{$\begin{array}{c}\text { Root } \\
\text { length } \\
(\mathrm{cm})\end{array}$} & Control & $3.58 \pm 1.3$ & - & 36.31 \\
\hline & & $0.5 \%$ & $4.0 \pm 0.4$ & +0.42 & 10.0 \\
\hline & & $1.0 \%$ & $3.25 \pm 0.25$ & -0.33 & 7.69 \\
\hline & & $1.5 \%$ & $3.5 \pm 0.5$ & -0.08 & 14.28 \\
\hline & \multirow{4}{*}{$\begin{array}{c}\text { No. of } \\
\text { rootlets/pla } \\
\text { nt }\end{array}$} & Control & $7.33 \pm 1.24$ & - & 16.91 \\
\hline & & $0.5 \%$ & $8.0 \pm 2.16$ & +0.67 & 27.0 \\
\hline & & $1.0 \%$ & $10.0 * * \pm 3.0$ & +2.67 & 30.0 \\
\hline & & $1.5 \%$ & $6.33 \pm 3.03$ & -1 & 47.86 \\
\hline \multirow[t]{12}{*}{ KU300 } & \multirow{4}{*}{$\begin{array}{l}\text { Seedling } \\
\text { height } \\
\text { (cm) }\end{array}$} & Control & $8.74 \pm 2.81$ & - & 32.15 \\
\hline & & $0.5 \%$ & $10.5 * * \pm 2.09$ & +1.76 & 19.9 \\
\hline & & $1.0 \%$ & $11.9 * * \pm 5.23$ & +3.16 & 43.94 \\
\hline & & $1.5 \%$ & $7.3 \pm 0.061$ & -1.44 & 0.83 \\
\hline & \multirow{4}{*}{$\begin{array}{l}\text { Root } \\
\text { length } \\
(\mathrm{cm})\end{array}$} & Control & $2.78 \pm 1.633$ & - & 57.55 \\
\hline & & $0.5 \%$ & $4.97 * * \pm 1.225$ & +2.19 & 24.54 \\
\hline & & $1.0 \%$ & $3.6 \pm 0.565$ & +0.82 & 15.55 \\
\hline & & $1.5 \%$ & $4.26 * * \pm 0.249$ & +1.48 & 5.63 \\
\hline & \multirow{4}{*}{$\begin{array}{c}\text { No. of } \\
\text { rootlets/pla } \\
\text { nt }\end{array}$} & Control & $7.14 \pm 3.18$ & - & 44.53 \\
\hline & & $0.5 \%$ & $9.25 * * \pm 1.47$ & +2.11 & 15.89 \\
\hline & & $1.0 \%$ & $9.33 * * \pm 2.05$ & +2.19 & 21.97 \\
\hline & & $1.5 \%$ & $3.33 * * \pm 0.47$ & -3.81 & 14.11 \\
\hline
\end{tabular}

$\mathrm{CV}=$ Coefficient of variation $* *$ Significant at $\mathrm{p}<0.05$

Table 4 Effect of SA on plant height, leaves/plant and branches/plant under field conditions.

\begin{tabular}{llcl}
\hline Treatment & Concentration & Mean \pm S.D. & Reduction (\%) \\
\hline & & Plant height $(\mathrm{cm})$ & - \\
Control & - & $10.95 \pm 3.79$ & 47.48 \\
SA & $0.5 \%$ & $5.75 \pm 1.30$ & 36.98 \\
SA & $1.0 \%$ & $6.9 \pm 1.14$ & 52.05 \\
SA & $1.5 \%$ & $5.25 \pm 0.5$ & - \\
& & Number of leaves/plant \\
Control & - & $10.54 \pm 4.36$ & 69.25 \\
SA & $0.5 \%$ & $3.16 \pm 1.16$ & 65.46 \\
SA & $1.0 \%$ & $3.6 \pm 1.14$ & 54.07 \\
SA & $1.5 \%$ & $4.75 \pm 0.5$ & - \\
& & Number of branches/plant & 16.66 \\
Control & - & $3 \pm 1$ & 13.33 \\
SA & $0.5 \%$ & $2.5 \pm 0.57$ & 16.66 \\
SA & $1.0 \%$ & $2.6 \pm 0.57$ & \\
SA & $1.5 \%$ & $2.5 \pm 0.70$ & \\
\hline
\end{tabular}

Dose of SA treatment were also reported in $\mathrm{M}_{1}$ and $\mathrm{M}_{2}$ generations of Nigella sativa L., Plantago ovata F. and Trigonella foenum graceum L. [23] and in $\mathrm{M}_{1}$ musk okra [31] and Lycopersicon esculentum L. [27].

\section{Conclusion}

The two black gram varieties under investigation were quite sensitive to SA treatment in all the concentrations. Most of the traits studied exhibited reduction. There was increment in root growth in both the varieties. Such plants with better root system may be selected with other traits undisturbed. Such mutant plants can be tested for soil with low organic contain such as the site where the study was carried out. The mutant population developed may used to screen for plant with potential for higher yield the next generations.

\section{Acknowledgement} acknowledged.

The support provided by Dr. A. K. Saikia, USTM, in carrying out the project work is gratefully 


\section{References}

[1] F.L. Fery, New opportunities in Vigna, In : Janick J, Whipkey A (eds) Trends in new crops and new uses, ASHS press, Alexandria, 2002, 424- 428.

[2] M F El-Karamay, Double purpose (Forage and seed) of mung bean production 1-effect of plant density and forage cutting date on forage and seed yields of mungbean (Vigna radiata L. Wilczck), Res. J. Agric. Biol. Sci., 2, 2006. 162 - 165.

[3] D Munro and E.Small, Vegetables of Canada, NRC Research Press Scientific Publishing, Canada, 1997, pp. $245-247$.

[4] Ali, M. and S.Kumar, Pulses production in India: Present status and future strategies, Yojana(September issue), 2006,13-15.

[5] M C Kharkwal, Induced mutations in chickpea (Cicer arietinum L.) III. Frequency and spectrum of viable mutations. Indian J. Genet., 59, 1999, 451-64.

[6] M A Rajput, G. Sarwar and K.A. Siddiqui, Development of high yielding mutants in lentil. Mut. Breed. Newslet., 45, $2000,35-6$.

[7] M Singh and V.P. Singh, Genetic analysis of certain mutant lines of urdbean for yield and quality traits in M4 generation, Ind. J. Pulses Res, 14(1), 2001, 60-62.

[8] S Khan, M.R.Wani and K. Parveen, Induced genetic variability for quantitative traits in Vigna radiata (L.) Wilczek. Pakistan J. Bot., $36,2004,845-50$

[9] SN Acharya, J.E. Thomas and S.K. Basu, Improvement in the medicinal and nutritional properties of fenugreek (Trigonella foenumgraecum L.). In: Acharya S.N, Thomas J.E. (Eds) Advances in medicinal plant research, Research signspot, Trivandrum, Kerala, India, 2007.

[10] NP Dubinin, Problems of radiation genetics. Oliver and Boyd, London, 1961.

[11] TM Shaha, J.I. Mirza, M.A. Haq and B.M. Atta, Induced genetic variability in chickpea (Cicer arietinum L.)II. Pak.J.Bot., 40(2), 2008, 605-613.

[12] N Menda, Y. Semel, D. Peled, Y. Eshed and D. Zamir, In silico screening of a saturated mutation library of tomato, Plant J., 38, 2004, 861-872.

[13] Y Kim, K.S. Schumaker and J.K. Zhu, EMS mutagenesis of Arabidopsis, Meth. Mol. Biol., 323, 2006, $101-103$.

[14] AW Kleinhofs, M. Owais and R.A. Nilan, Azide. Mutation Research, 55, 1978, 165-195.

[15] WM Owais and A. Kleinhofs, Metabolic activation of the mutagen azide in biological systems, Mutation Research ,197, 1988, 313323.

[16] P. Padavai and D. Dhanavel, Effect of EMS, DES and Colchicine treatment in soybean. Crop Res., 28(1,2 \& 3), 2004, 118-120.

[17] R. Singh and C.R. Kole, Effect of mutagenic treatments with EMS on germination and some seedling parameters in mungbean, Crop Res., 30(2), 2005, 236-240.

[18] K. Parveen, Mutation studies with early generation selection for polygenic variability in chickpea (Cicer arietinum L.). Ph. D. Thesis. Aligarh Muslim University, Aligarh, 2006.

[19] OW Pearson, R.A. Nillan and C. Sander, The effect of sodium azide on cell processes in the embryonic barley shoot, Radiat Bot., $15,1975,315-322$

[20] A Kleinhofs, R.L.Warner, F.J. Muehlbauer and R.A. Nilan, Induction and selection of specific gene mutations in Hordeum and Pisum, Mutation Research, 51, 1978b, 29-35.

[21] J.K. Mensah, P.A. Akomeah and E.O. Ekpekurede, Gamma irradiation induced variation of yield parameters in cowpea (Vigna unguiculata (L) Walp), Global J Pure Appl Sci., 11(3), 2005, 327-330.

[22] ML Gaibriyal, T. Bini and S.L. Sapna, Mutagenic Sensitivity in Early Generation in Black Gram, Asian Journal of Agricultural Sciences, 1(1), 2009, 9-11.

[23] P Rajani, D. Vineeta and B.R. Chaudhary, Comparative spectrum of sodium azide responsiveness in plants, World J of Agri Sci. 7(1), 2011, 104-108.

[24] P Snehal and K. Madhukar, Biological Effect of Sodium azide and Colchicine on Seed Germination and Callus Induction in Stevia Rebaudiana, Asian J Exp Biol Sci. 3(1), 2012, 93-98.

[25] RA Nilan, E.G. Sideris and A. Kleinhofs, Azide - a potent mutagen, Mutation Research, 17, $1973,142-144$.

[26] A Afsar, Rutger and R.A. Nilan, Mutagenic effects of Sodium Azide in Rice, Crop Sci., 20, 1980, $661-668$.

[27] AK Adamu and H. Aliyu, Morphological effects of sodium azide on tomato (Lycopersicon esculentum Mill), Sci. Worl J,. 2(4), 2007, 9-12.

[28] AB Traiq, S. Monika and M. Anis, Comparative analysis of mitotic aberrations induced by diethyl sulphate (DES) and sodium azide in Vicia faba L. (Fabaceae), Pakistan J of Bio Sci., 10(5), 2007, 783-787.

[29] CP Srivastava, A.K. Singh, V.K. Singh and K. Sanjeev, Synergistic effect of sodium azide on gamma-irradiated seeds of peas (Pisum sativum L), Veg Sci., 35(2), 2008, 127-131.

[30] SA Sheikh, M.R. Wani, M.A. Lone, M.A. Tak and N.A. Malla, Sodium azide induced biological damage and variability for quantitative traits and protein content in wheat [Triticum aestivum L.], J Plant Genomics, 2(1): 2012, 34-38.

[31] Ashish R., Warghat N., Rampure H., Prashant W. (2011) Effect of sodium azide and gamma rays treatments on percentage germination, survival, morphological variation and chlorophyll mutation in musk okra (Abelmoschus moschatus L.): Inte J Pharmacy \& Pharmaceutical Sci. 3(5): 484-486.

[32] Khan S., Al-Qurainy F., Firoz A. (2009) Sodium Azide: a Chemical Mutagen for Enhancement of Agronomic Traits of Crop Plants Environ. We Int. J. Sci. Tech. 4:1-21. 